\title{
CRACKERS MODIFIKASI F100 DENGAN SUBSTITUSI TEPUNG LABU KUNING SEBAGAI ALTERNATIF PEMBERIAN MAKANAN TAMBAHAN BAGI BALITA GIZI BURUK
}

\author{
Ria Ambarwati* ${ }^{*}$; Yuwono Setiadi \\ Jurusan Gizi ; Poltekkes Kemenkes Semarang \\ Jl. Wolter Monginsidi ; Pedurungan ; Semarang
}

\begin{abstract}
Abstrak
Pemberian F100 kepada balita gizi buruk di masyarakat masih mengalami kendala, terutama dalam pembuatan, higien sanitasi orang yang membuat dan peralatan, sehingga perlu dipertimbangkan bentuk alternatif formula makanan untuk balita gizi buruk dalam bentuk crackers modifikasi F100 dengan substitusi tepung labu kuning sebagai pangan lokal yang mengandung tinggi beta karoten. Penelitian ini adalah eksperimen murni dengan Rancangan Acak Lengkap 1 faktor, yaitu konsentrasi substitusi serta 5 taraf perlakuan, yaitu $0 \%, 10 \%, 20 \%, 30 \%$, $40 \%$ dengan jumlah ulangan 3 kali. Tahapan penelitian yang dilakukan terdiri dari pembuatan tepung labu kuning, pembuatan crackers modifikasi F100, pengujian nilai gizi serta daya terimanya. Jumlah ulangan 3 kali. Semakin besar konsentrasi substitusi tepung labu kuning menurunkan kadar lemak, protein crackers modifikasi F100. Crackers modifikasi F100 yang paling disukai balita adalah crackers dengan substitusi tepung labu kuning 10\%. Ada perbedaan nilai gizi (lemak, protein dan beta karoten), tekstur dengan substitusi tepung labu kuning berbagai konsentrasi.
\end{abstract}

Kata kunci: crackers ; F100 ; tepung labu kuning

\begin{abstract}
[CRACKERS MODIFICATION F100 WITH SUBSTITUTION OF PUMPKIN AS ADDITIONAL ALTERNATIVE FOOD FOR EARLY CHILDREN] Provision of F100 to under-five child malnutrition at the community level is still experiencing difficulties, especially in the production process, personal hygiene, sanitation and cleanliness of the equipment. It is therefore necessary to consider an alternative feeding formula for under-five child malnutrition. We came up by F-100 modified crackers F-100 with substitution of pumpkin powder as local food product containing high beta carotene. This study was using experimental research with single-factor completely randomized design. The substitution concentrations and five treatment levels were $0 \%, 10 \%, 20 \%$, $30 \%$ and $40 \%$ with three-times of repetitions. The research process consists of pumpkin powder production, F-100 modified crackers production, nutritional and sensory analysis. The result showed the higher substitution concentration of pumpkin powder reduced its fat level. The most under-five children preferred were F-100 modified crackers with $10 \%$ s substitution of pumpkin powder. There were significant differences in nutritional value (fat, protein, and beta carotene) and texture with various concentration substitutions of pumpkin powder.
\end{abstract}

Keywords : crackers ; F100 ; pumpkin powder

\section{Pendahuluan}

Gizi buruk adalah bentuk terparah dari

\footnotetext{
$\left.{ }^{*}\right)$ Ria Ambarwati

E-mail: ria_mgiz09@yahoo.com
}

proses terjadinya kekurangan gizi menahun yang disebabkan rendahnya konsumsi energi dan protein (KEP) dalam makanan sehari hari (Admin, 2008). Dampak jangka pendek gizi buruk terhadap perkembangan anak menurut 
Nency \& Arifin (2005), diantaranya menjadikan anak apatis, gangguan bicara dan gangguan perkembangan yang lain. Sedangkan dampak jangka panjang adalah penurunan skor intelligence quotient (IQ), penurunan perkembangan kognitif, penurunan integrasi sensori, gangguan pemusatan perhatian, gangguan penurunan rasa percaya diri dan tentu saja merosotnya prestasi akademik di sekolah.

Secara nasional menurut Riskesdas 2013 angka prevalensi balita gizi buruk 5,7\% . Meningkat dibandingkan dengan angka prevalensi tahun 2007 ( 5,4\%) dan tahun 2010 $(4,9 \%)$. Kota Semarang prevalensi gizi buruk menunjukkan peningkatan dari $0,69 \%$ tahun 2014 menjadi 0,87\% pada tahun 2015 .

Salah satu upaya penanganan balita gizi buruk di Kota Semarang dengan program pemeriksaan kesehatan komprehensif dan Pemberian Makanan Tambahan (PMT) dalam bentuk F100. Formula WHO F100 merupakan formula makanan yang direkomendasikan WHO yang mengandung energi, lemak dan protein yang tinggi dalam penanganan balita gizi buruk.

Pemberian F100 kepada balita gizi buruk di masyarakat masih mengalami kendala, terutama dalam pembuatan, higien sanitasi orang yang membuat dan peralatan. Selain itu hasil evaluasi program penanganan secara komprehensif di Kota Semarang pada balita gizi buruk tahun 2014 menunjukkan bahwa 11 (31,4\%) balita tidak bisa menghabiskan F100 persekali saji, sehingga perlu dipertimbangkan bentuk alternatif formula makanan untuk balita gizi buruk. Alternatif tersebut dengan pembuatan makanan dalam bentuk crackers dengan menggunakan bahan dasar formula WHO F100 dengan mensubsitusi tepung labu kuning.

Pemberian F100 dengan kondisi tidak higienis mengakibatkan pertumbuhan bakteri patogen, sehingga perlu dikembangkan makanan terapi dengan sumber pangan lokal yang tersedia, murah dan dapat diterima. Local ready to use therapeutic food (LRUTF) yang dibuat dari kacang tanah $(25 \%)$, susu bubuk $(30 \%)$, gula (30\%), dan minyak sayur $(15 \%)$ dan LRUTF dapat meningkatan berat badan dengan cepat dibanding dengan F100 pada pasien dengan severe acute malnutrition (SAM) selama fase rehabilitasi (Thakur GS et.al., 2012)

Labu kuning (Cucurbita maxima) memiliki potensi sebagai sumber provitamin A nabati berupa $\beta$-karoten. Kandungan provitamin A dalam labu kuning sebesar $767 \mu \mathrm{g} / \mathrm{g}$ bahan. Selain itu, labu kuning juga mengandung vitamin $C$, serat dan karbohidrat yang cukup tinggi (Gardjito, 2005). Labu kuning juga merupakan tanaman musiman, sehingga produksi labu kuning akan sangat besar ketika musimnya tiba. Meskipun daya simpannya cukup lama namun labu kuning mudah rusak dalam pengangkutan. Tingginya produksi labu kuning di Indonesia tidak berimbang dengan pemanfaatan dari labu kuning tersebut. Oleh karena itu, perlu adanya olahan dari labu kuning yang lebih bervariasi namun tetap mempertahankan nilai gizi yang terdapat di dalam labu kuning tersebut (Chatrine Chrisandy Purwanto, dkk, 2013)

Crackers dengan bahan dasar modifikasi F100 dengan substitusi tepung labu kuning diharapkan dapat dijadikan makanan alternatif bagi anak balita kurang gizi. Pembuatan crackers dengan bahan dasar F100 dan tepung labu kuning tentu akan membawa pengaruh terhadap nilai gizi dan daya terima sehingga dalam penelitian ini perlu diketahui bagaimana nilai gizi dan daya terima crackers tersebut.

\section{Metode}

Penelitian menggunakan pola Rancangan Acak Lengkap yaitu menguji pengaruh substitusi tepung labu kuning terhadap kadar protein, lemak, beta karoten dan daya terima crackers modifikasi F100 sebagai alternatif Pemberian Makanan Tambahan Balita Gizi Buruk. Konsentrasi substitusi tepung labu kuning dengan taraf $10 \%, 20 \%, 30 \%, 40 \%$ dan $0 \%$, sebagai kontrol. Pengulangan dilakukan sebanyak 3 kali.

Pelaksanaan penelitian dibagi menjadi 3 tahap, yaitu tahap pertama, pembuatan tepung labu kuning. Tepung labu kuning dibuat dengan cara mengeringkan terlebih dahulu labu kuning yang didapat dengan menggunakan oven, menghaluskannya dengan blender dan mengayak dengan ayakan ukuran 80 mesh serta pengujian kimiawi yang meliputi kadar protein, lemak, beta karoten dari tepung labu kuning tersebut. Tahap kedua, pembuatan Crackers modifikasi F100 dan pengujian kadar protein, lemak dan beta karoten. Tahap ketiga, pengujian daya terima pada panelis agak terlatih, jumlah panelis sebanyak 25 orang dan pada anak balita, jumlah anak balita sebanyak 20 orang.

\section{Hasil dan Pembahasan}


1. Pengaruh substitusi tepung labu kuning dalam berbagai konsentrasi pada pembuatan crackers modifikasi F100 terhadap kadar lemak.

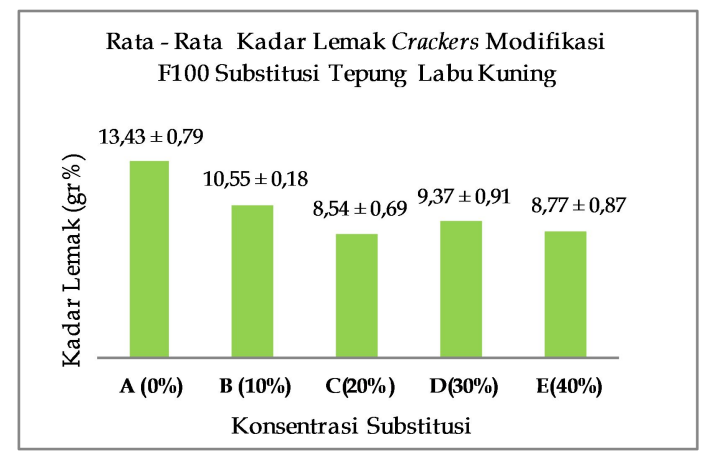

Gambar 1. Rata-Rata Kadar Lemak Crackers Modifikasi F100 Substitusi Tepung Labu Kuning

Hasil uji ANOVA menunjukkan ada perbedaan kadar lemak dengan crackers dengan substitusi tepung labu kuning pada berbagai konsentrasi $(p=0,000 ; p<0,01)$. Perbedaan kadar lemak dikarenakan adanya perbedaan konsentrasi substitusi tepung labu kuning yang digunakan dalam pembuatan crackers tersebut.

Tepung labu kuning dalam pembuatan crackers berfungsi sebagai pengganti sebagian dari tepung terigu. Tepung labu kuning memiliki kadar lemak yang relatif rendah, yaitu sekitar 0,5 gr\% (KPI, 2009) sehingga dengan mensubstitusikan tepung labu kuning maka kadar lemak produk yang dihasilkan justru akan menurun. Hal ini sesuai hasil penelitian, semakin besar konsentrasi substitusi tepung labu kuning yang digunakan maka kadar lemak crackers yang dihasilkan juga semakin rendah.

2. Pengaruh substitusi tepung labu kuning dalam berbagai konsentrasi pada pembuatan crackers modifikasi F100 terhadap kadar protein.

Rata - Rata Kadar Protein Crackers Modifikasi F100 Substitusi Tepung Labu Kuning

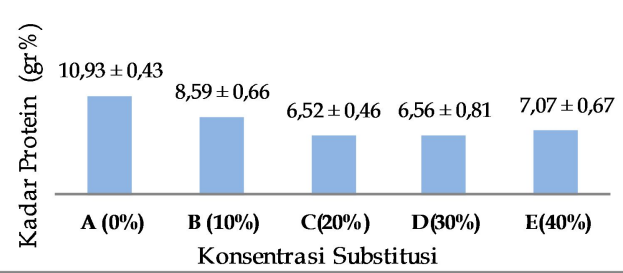

Gambar 2. Rata-Rata Kadar Protein Crackers Modifikasi F100 Substitusi Tepung Labu Kuning
Hasil uji ANOVA menunjukkan ada perbedaan kadar protein dengan crackers dengan substitusi tepung labu kuning pada berbagai konsentrasi ( $p=0,000 ; p<0,01)$. Perbedaan konsentrasi substitusi tepung labu kuning mempengaruhi kadar protein yang digunakan dalam crackers tersebut.

Tepung labu kuning dalam pembuatan crackers juga berfungsi sebagai pengganti sebagian dari tepung terigu. Tepung labu kuning memiliki kadar protein yang relatif rendah, yaitu sekitar 1,7 gr\% (KPI, 2009) sehingga dengan mensubstitusikan tepung labu kuning ke dalamnya maka kadar protein produk yang dihasilkan justru akan menurun. Hal ini sesuai hasil penelitian ini, semakin besar konsentrasi substitusi tepung labu kuning yang digunakan maka kadar protein crackers yang dihasilkan juga semakin rendah.

3. Pengaruh substitusi tepung labu kuning dalam berbagai konsentrasi pada pembuatan crackers modifikasi F100 terhadap kadar beta karoten.

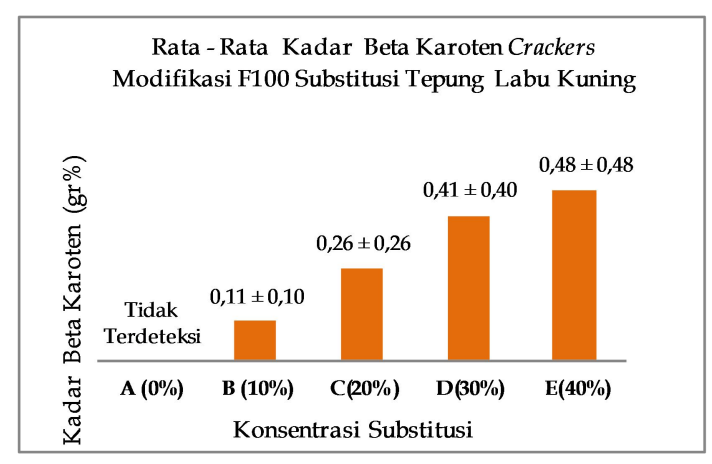

Gambar 3. Rata-Rata Kadar Beta Karoten Crackers Modifikasi F100 Substitusi Tepung Labu Kuning

Hasil uji ANOVA menunjukkan ada perbedaan kadar beta karoten crackers dengan substitusi tepung labu kuning pada berbagai konsentrasi $\quad(p=0,000 ; p<0,01)$. Semakin besar konsentrasi substitusi tepung labu kuning yang digunakan maka kadar beta karoten crackers yang dihasilkan semakin besar. Anggreni, dkk (2006), menyatakan bahwa tepung labu kuning merupakan tepung-tepungan yang potensial kadar beta karotennya, dengan kadar beta karotennya sekitar 180 ug.

Tepung terigu sebagai bahan dasar dalam pembuatan crackers tidak memiliki beta karoten, sehingga dengan 
mensubstitusikan tepung labu kuning ke dalam pembuatan crackers maka dapat meningkatkan kadar beta karoten dari produk yang dihasilkan.

4. Pengaruh substitusi tepung labu kuning dalam berbagai konsentrasi dalam pembuatan crackers modifikasi F100 terhadap daya terima panelis.

\section{1) Warna}

Penilaian panelis terhadap warna diketahui bahwa crackers dengan substitusi tepung labu kuning crackers yang paling disukai adalah crackers dengan substitusi $10 \%$ dengan rata-rata jumlah skor 3,46 (sangat suka).

Hasil uji Friedman menunjukkan tidak ada perbedaan penilaian panelis terhadap warna crackers dengan substitusi tepung labu kuning dalam berbagai kosentrasi $(p=0,018, p>0,01)$. Crackers memiliki warna yang relatif sama, yaitu kuning kecoklatan. Konsentrasi substitusi yang lebih besar memiliki kecenderungan warna kuning yang lebih gelap, hal ini dikarenakan selain warna dari bahan baku tepung labu kuning yang berwarna kuning juga terjadi reaksi Mailard yaitu terjadinya warna coklat pada crackers dikarenakan adanya reaksi antara gugus amin bebas dari asam amino atau protein yang ada pada bahan. Semakin besar konsentrasi yang digunakan maka warna yang dihasilkan akan semakin gelap (Asmaraningtyas, 2014).

\section{2) Aroma}

Penilaian panelis terhadap aroma menunjukkan crackers yang paling disukai adalah crackers dengan substitusi 10\% dengan rata-rata jumlah skor 3,30 (suka).

Hasil analisis uji Friedman menunjukkan tidak ada perbedaan penilaian panelis terhadap aroma crackers dengan substitusi tepung labu kuning dalam berbagai konsentrasi $(p=0,363, \quad p>0,01)$. Crackers memiliki aroma yang relatif sama, yaitu aroma khas dari labu kuning, hal ini dikarenakan labu kuning memiliki sifat yang spesifik dengan aroma yang khas (Asmaraningtyas, 2014). Hasil penelitian, menunjukkan adanya kecenderungan panelis menyukai crackers dengan konsentrasi substitusi tepung labu kuning yang rendah/sedikit.

\section{3) Tekstur}

Penilaian panelis terhadap tekstur diketahui bahwa crackers dengan substitusi tepung labu kuning yang paling disukai adalah crackers dengan substitusi $10 \%$ dengan rata-rata jumlah skor 3,56 (sangat suka).

Hasil uji Friedman menunjukkan ada perbedaan penilaian panelis terhadap tekstur crackers dengan substitusi tepung labu kuning dalam berbagai kosentrasi $(p=0,000, \quad p<0,01)$. Crackers dengan konsentrasi substitusi tepung labu kuning $10 \%$ memiliki tekstur yang renyah dibandingkan dengan konsentrasi yang lainnya.

Tepung labu kuning memiliki protein-gluten yang relatif rendah dibandingkan dengan tepung terigu yang merupakan bahan utama dalam pembuatan crackers. Rendahnya kandungan gluten yang terdapat pada tepung labu kuning menyebabkan rendahnya volume gas yang dihasilkan saat fermentasi (Asmaraningtyas, 2014). Rendahnya volume gas yang dihasilkan sangat berpengaruh terhadap terbentuknya rongga-rongga udara yang biasanya ada dalam produk crackers. Keberadaan rongga tersebut sangat berpengaruh terhadap kerenyahan dari produk crackers.

Semakin besar kandungan protein (gluten) pada bahan yang kemudian dikombinasikan dengan pengolahan fermentasi maka produk yang dihasilkan akan semakin renyah, demikian juga sebaliknya. Selain itu semakin kerasnya tekstur produk yang dihasilkan juga dapat dikarenakan adanya penambahan mineral mix dalam pembuatannya. Salah satu komposisi mineral mix adalah Magnesium Chloride $(\mathrm{MgCl}) . \mathrm{MgCl}$ ini merupakan salah satu jenis koagulan yang dapat menggumpalkan protein dari suatu bahan, termasuk protein yang terdapat dalam bahan penyusun crackers, ditambah lagi dengan adanya penggunaan panas dalam pembuatan produk crackers ini maka hal ini akan lebih mempercepat penggumpalan protein bahan. 
Penggumpalan protein dari bahan akan sangat berpengaruh terhadap tekstur dari produk yang dihasilkan, tekstur akan terasa lebih keras (Susilowati,1989).

\section{4) Rasa}

Penilaian panelis terhadap rasa menunjukkan panelis lebih menyukai produk crackers dengan substitusi yang $10 \%$ dengan rata-rata jumlah skor 3,30 (suka).

Hasil analisis uji Friedman menunjukkan tidak ada perbedaan penilaian panelis terhadap rasa crackers dengan substitusi tepung labu kuning dalam berbagai konsentrasi $(\mathrm{p}=0,000, \mathrm{p}<$ $0,01)$.

Crackers dengan konsentrasi substitusi tepung labu kuning 10\% memiliki rasa yang lebih enak dibandingkan dengan konsentrasi yang lainnya. Tepung labu kuning memiliki rasa yang spesifik dan khas sehingga jika dijadikan campuran dalam pembuatan produk dan digunakan dalam konsentrasi yang cukup tinggi maka rasa khasnya akan semakin tajam terasa indera perasa (Asmaraningtyas, 2014).

5. Pengaruh substitusi tepung labu kuning dalam berbagai konsentrasi dalam pembuatan crackers modifikasi F100 terhadap daya terima anak balita.

Crackers yang diuji daya terimakan pada populasi anak balita adalah crackers dengan konsentrasi substitusi tepung labu kuning 10\% dan 20\% (yang disukai panelis agak terlatih). Jumlah balita yang digunakan sebanyak 20 orang.

Produk crackers tersebut dapat dikatakan diterima jika $\geq 50$ populasi balita dapat menghabiskan $\geq 1 / 2$ porsi crackers yang disajikan. Hasil uji daya terima crackers pada anak balita dapat dilihat pada Tabel 1.

Tabel 1. Uji Daya Terima Crackers pada Anak Balita

\begin{tabular}{ccc}
\hline \multirow{2}{*}{ Besar Porsi } & \multicolumn{2}{c}{ Jumlah Balita (orang) } \\
\cline { 2 - 3 } & $\begin{array}{c}\text { Crackers } \\
\text { Substitusi 10\% }\end{array}$ & $\begin{array}{c}\text { Crackers } \\
\text { Substitusi } 20 \%\end{array}$ \\
\hline$<1 / 2$ porsi & $8(40 \%)$ & $10(50 \%)$ \\
$\geq 1 / 2$ porsi & $12(60 \%)$ & $10(50 \%)$ \\
Total & $20(100 \%)$ & $20(100 \%)$ \\
\hline
\end{tabular}

Hasil penelitian menunjukkan bahwa crackers dengan konsentrasi substitusi tepung labu kuning $10 \%$ dapat diterima oleh anak balita.

\section{Simpulan dan Saran}

Ada perbedaan nilai gizi (lemak, protein dan beta karoten), tekstur dengan substitusi tepung labu kuning berbagai konsentrasi. Perlu ada pengembangan produk lain seperti cookies, biskuit dengan berbasis F100.

\section{Ucapan Terima Kasih}

Ucapan terimakasih disampaikan kepada Direktur Poltekkes Kemenkes Semarang, Ketua Jurusan, Ketua Prodi, keluarga, mitra sejawat, responden, dan semua pihak yang terlibat dalam penelitian ini.

\section{Daftar Pustaka}

Azizah, 2012. Pemanfaatan Tepung Labu Kuning (Cucurbita moschata) pada Pembuatan Kue sebagai Makanan Tambahan Berbasis Potensi Lokal di Desa Tanduk Kecamatan Ampel Kabupaten Boyolali (Uji Kadar Provitamin A dan Daya Terima). Universitas Negeri Semarang.

Anggraini, S., I. Ratnawati, dan A. Murdjiati, 2006. Pengkayaan B-karoten Mie Ubi Kayu dengan Tepung Labu Kuning (Curcubita maxima Dutchenes) Majalah Ilmu dan Teknologi Pangan Pertanian, Vol. XXVI, No.2 : 81-82.

Asmaraningtyas, D, 2014. Kekerasan, warna dan daya terima biskuit yang disubstitusi tepung labu kuning. Naskah Publikasi. Universitas Muhammadiyah Surakarta.

Ciliberto MA, Sandige H, Ndekha MJ, Ashorn P, Briend A, Ciliberto HM, et al. Comparison of home-based therapy with ready-to-use therapeutic food with standard therapy in the treatment of malnourished Malawian children: a controlled, clinical effectiveness trial. Am J Clin Nutr. 2005;81:864-70.

Dani, 2011. Pengaruh konsumsi biskuit terhadap status gizi dan tingkat morbiditas balita yang berstatus gizi buruk atau kurang di tiga tipologi wilayah kabupaten Sukabumi URI:

http://repository.ipb.ac.id/handle/12345 $\underline{6789 / 54381}$ 
Dahlan, 2009. Statistik untuk Kedokteran dan Kesehatan, Salemba Medika, Jakarta

Depkes R.I. 2008. Pedoman Pelaksanaan Respon Cepat Penanggulangan Gizi Buruk.

Departemen Kesehatan RI. 2003. Pedoman penatalaksanaan gizi buruk secara rawat jalan untuk Puskesmas. Jakarta : Departemen Kesehatan RI

Departemen Kesehatan RI. 2009. Pedoman penanganan dan pelacakan gizi buruk. Jakarta : Departemen Kesehatan RI

Departemen Kesehatan RI. 2011. Pedoman pelayanan gizi buruk. Jakarta : Departemen Kesehatan RI

Dinas Kesehatan Kota Semarang, 2015. Profil Dinas Kesehatan Kota 2014

Dinas Kesehatan Kota Semarang. 2015 Laporan Program Penanganan Komprehensif Gizi Buruk di Kota Semarang Tahun 2014.

Driyani, Yuliana, 2007. Biscuit Crackers Substitusi Tepung Tempe Kedelai sebagai Alternatif Makanan Kecil Bergizi Tinggi, Semarang : Universitas Negeri Semarang.

Diop EHI, Dossou NI, Ndour MM, Briend A, Wade S. Comparison of the efficacy of a solid ready-to-use food and a liquid, milk-based diet for the rehabilitation of severely malnourished children: a randomized trial. Am J Clin Nutr. 2003;78: 302-7.

Gardjito, Murdijati dan Theresia Fitria Kartika Sari. 2005. Pengaruh Penambahan Asam Sitrat dalam Pembuatan Manisan Kering Labu Kuning (Cucurbita maxima) terhadap Sifat-sifat Produknya. Jurusan Teknologi Pangan dan Hasil Pertanian Fakultas Teknologi Pertanian UGM.

Kamsiati, E. 2010. Tepung Labu Kuning Pembuatan dan Pemanfaatannya. Yogyakarta : Kanisius

Kementerian Kesehatan RI. 2013. Bagan Tatalaksana Anak Gizi Buruk Buku I. Jakarta : Kementerian Kesehatan RI

Kementerian Kesehatan RI. 2013. Bagan Tatalaksana Anak Gizi Buruk Buku II. Jakarta : Kementerian Kesehatan RI
Kemenkes RI, 2013. Hasil Riskesdas 2013 diunduh pada tanggal 6 April 2015 pada www.depkes.go.id/resources/download/. ../Hasil\%20Riskesdas \%202013.pdf.

Nency, Y. \& Arifin, M.T. 2005. Gizi Buruk, Ancaman Generasi yang Hilang. Jurnal Inovasi Online Kesehatan, Vol.5, No. XVII.

Purwanto, dkk, 2013. Kajian Sifat Fisik dan Kimia Tepung Labu Kuning (Cucurbita maxima) dengan Perlakuan Blanching dan Perendaman Natrium Metabisulfit $\left(\mathrm{Na}_{2} \mathrm{~S}_{2} \mathrm{O}_{5}\right)$

Pahlevie, I. 2011. Pengaruh Perlakuan Pengukusan dan Penentuan Proporsi Sari Buah Labu Kuning (Curcubita Maxima) dalam Pembuatan Minuman Ringan. Skripsi, Departemen teknologi Hasil Pertanian, Fakultas Teknologi Pertanian, Universitas Jember, Jember.

PERSAGI, 2009. Komposisi Pangan Indonesia. Jakarta

PERSAGI. 2005. Daftar Komposisi Bahan Makanan. Jakarta: Persatuan Ahli Gizi Indonesia

Sudarmadji, S., B Haryono, dan Suhardi. 2007. Prosedur Analisa Bahan Makanan. Yogyakarta. Penerbit: Liberty

Soekarto, S.T. 2007. Penilaian Organoleptik Untuk Industri Pangan dan Hasil Pertanian. Penerbit: Bhratara Karya Aksara, Jakarta.

Supariasa. 2012. Penilaian Status Gizi. Jakarta. Penerbit: Buku Kedokteran

Susilowati Tri, 1989. Pembuatan Tahu Sutera. Buletin Pusbangtepa IPB. Vol 7(18) hal 57-63.

Thakur GS, HP Singh , Chhavi Patel. 2013. Locally-Prepared Ready-to-Use Therapeutic Food for Children with Severe Acute Malnutrition: A Controlled Trial. Indian Pediatr 2013;50: 295-299

Winarno. 1990. Gizi dan Makanan Bagi Bayi dan Anak Sapihan. Jakarta. Penerbit : Pustaka Sinar Harapan 